\title{
Gut microbiota and the human gut physiological changes
}

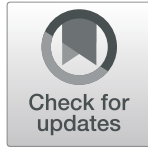

Ousman Bajinka ${ }^{1,2}$, Alansana Darboe ${ }^{3,4}$, Yurong Tan ${ }^{1,2^{*}} \mathbb{D}$, Khalid A. Abdelhalim ${ }^{5}$ and Lamin B. Cham ${ }^{6}$

\begin{abstract}
Background: The human gut can be colonized by number of microorganisms. The most studied are bacteria, which changes from birth to newborn born into adult-like gut microbiota. Much is known about the effects of dietary, medications, and lifestyles on the bacterial composition. However, the host physiological changes influencing the gut microbiota, the immediate consequences, and the possible gut microbiota therapy are not studied at length. This review is based profoundly on animal model studies through experimentation and some human clinical trials for the past 20 years.

Forward: The physiological factors studied to influences gut microbiota are bacterial mucosal receptors, mucin glycosylation, mucus, epithelial microvilli, and tight junction. Host secretions and immune response such as immunity, secretory A (slgA), inflammasome, innate immunity, immune response, glycans, bile acids, peristalsis, microRNA, and adhesion to intestinal glycans are as well found to confer variety of alterations on gut microbial flora.

Conclusion: Despite the resilience of the gut microbiota in response to changes, chain of events causes the imbalance microbiota. Increased pro-inflammatory potential with the help of cell barriers, host secretions, and immune response mediate gut recovery.
\end{abstract}

Keywords: Intrinsic factors, Intestinal mucosa, Gut microbes, Dysbiosis, Mucins, Glycans

\section{Introduction}

Diversity of bacterial population in the gut is associated with gut microbiota of healthy individuals. In contrast, reduced diversity is seen among diseased individuals and those with some abnormal physiological changes. The snowball effect of these physiological changes are seen when commensals are dominated by pathogonic strains. These might pose pathogenic futures and change the bacterial function metabolically in the gut (Qiu et al., 2020a, b).

Natural variations such as genes and mutation influence gut microbiota. The immune system, the intestinal mucosa, microbiota itself, diet, stress, chemotherapy, abuse of alcohol, and ingested antibiotics are the major

\footnotetext{
* Correspondence: yurongtan@csu.edu.cn

${ }^{1}$ Department of Microbiology, Central South University, Changsha, Hunan

Provinces, China

${ }^{2}$ China-Africa Research Centre of Infectious Diseases, School of Basic Medical Sciences, Central South University, Changsha 410078, Hunan, China Full list of author information is available at the end of the article
}

factors influencing gut bacterial population (Bajinka et al. 2020). Ingested antibiotics might be either for medication or through the consumption of antibiotictreated animal products. Probiotics and prebiotics supplementations and fecal microbiota transplantation (FMT) are studied to be promising interventions to restore gut microbiome (Bajinka et al. 2020).

Despite many previous efforts, the mechanisms underpinning dysbiosis still remain unclear (Bajinka et al. 2020). These are due to the limited microbial characterizing techniques (Bajinka and Secka, 2017). Also, the intricate interactions between interspecies such as the role of parasites, virus, bacteriophages, and fungi are not explored. In addition, combination with natural variations such as gene and mutations in the host, stress, secretions of bacterial toxins are yet to be deciphered (Thaiss et al. 2016). Until the knowledge gap of these effects is bridged to the role they play towards dysbiosis, the

(c) The Author(s). 2020 Open Access This article is licensed under a Creative Commons Attribution 4.0 International License, which permits use, sharing, adaptation, distribution and reproduction in any medium or format, as long as you give appropriate credit to the original author(s) and the source, provide a link to the Creative Commons licence, and indicate if changes were made. The images or other third party material in this article are included in the article's Creative Commons licence, unless indicated otherwise in a credit line to the material. If material is not included in the article's Creative Commons licence and your intended use is not permitted by statutory regulation or exceeds the permitted use, you will need to obtain permission directly from the copyright holder. To view a copy of this licence, visit http://creativecommons.org/licenses/by/4.0/. 
explicit role of microbiota on health and disease would not be better understood (Thaiss et al. 2016; Marques et al. 2010).

The trillions of microorganism residing in the gut are dispersedly distributed. These are not uniformly based on the biochemical and physiological properties in the human body. Acidophilic genera such as Streptococcus, Lactobacillus, Helicobacter pylori, Candida, and Peptostreptococcus are found in the stomach. The study of gut microbiome in health and disease are based on clusters of bacteria forming genera and rarely on the specific strain. The entire human body, with the exception of sterile organs harbors different bacterial populations. Studies have found Firmicutes and Bacteriodetes with $64 \%$ and $23 \%$ respectively as the most common in human gut. Actinobacteria and Proteobacteria are also occurring in varying percentages (Kasai et al. 2015). These microbes residing in the intestinal tract influence local and systemic process such as supplying vitamin, maturation of mucosal immunity, nutrient transformation, and influence the brain dopaminergic neurotransmitter (Marques et al. 2010; Arumugam et al. 2011).

The normal functioning of gut microbiota is more stable with diverse microbiota composition. Based on the recent Metagenomics analysis, a healthy human gut comprises mainly Bacteriodetes, Firmicutes, Actinobacteria, and Proteobacteria (Kasai et al. 2015).

Due to the biochemical niches in the gut, microbes developed resiliency in response to the host's lifestyle. For example, the time and type of food consume by the host influence the group of distinct phyla or class. The more abundant they are with respect to phyla, the more adaptable to any biochemical changes (Saha et al. 1983). The energy of the specific phyla or family of these bacteria is generally derived via fermentation and sulfate reduction of dietary and host carbohydrates. The 'survival of the fittest' existing among the microbes can be observed through their phenotypic traits (Ley et al. 2008; Saha et al. 1983).

This review aims at digging into the knowledge gap regarding physiological factors influencing gut microbes, the alterations caused in the gut, the immediate consequences and their alternative gut therapy. We focus mainly on mucus layers, epithelial microvilli, and tight junctions (TJs), immune factors, inflammasome, and host secretions. The review dwells on studies centered on a wide range of microbiota associated based on animal model. In addition, this review has much evidence on randomized clinical trials over the last 20 years. We deciphered on the varying dysbiosis caused by specific physiological changes.

\section{Mucus layers and bacterial mucosal receptors}

Human small intestine comprises duodenum, jejunum and ileum. It helps in digestion and nutrient absorption.
Large intestines are cecum, colon and rectum for the absorption of digested food and formation of feces. These anatomies are specific to their functions. The layers that are in contact with the intestinal activity are muscularis propria, the submucosa, and the most concentrated mucosa. The concentration of enterocytes coming from the villi on the surface of the small intestinal wall gives rise to microvilli. Microvilli are specific for absorption of nutrients as part of the digestive process. Colonocytes absorb water in the colon while lubricating the intestinal contents. Through the direct competition for nutrients, microbiota increase mucus layer on the intestinal mucosa. This process stimulates the immune system of the gut with the help of gut-associated lymphatic tissue (GALT) (SorgJA, 2008).

Mucus layer are made up of inner, stratified, and are firmly adhered to the epithelial cells. They produce digestive juices and other biochemical products like enzymes. In addition to the protective effects to the gut, these biochemical products are crucial in distributing nutrients between the host cells and the resident microbes (SorgJA, 2008). Transmembrane mucins found on the apical surface of microvilli such as MUC3, MUC12, MUC13, and MUC17 functionally form a layer. This is protective in nature and works as diffusion barrier in the gut. They maintain the integrity of the surface epithelial layer and in interaction with different PDZproteins; they regulate the membrane channels and signal proteins (Hooper, 2010). The protective mechanisms for epithelium from direct contact with microbes are accomplished when goblet cells secrete mucus that lines the gastrointestinal tract.

Instead of the microbes to feed on the epithelium, the intestinal mucus serves as sources of carbohydrates from the mucins (glycan chains) (SorgJA, 2008). Moreover, the daily production of mucus, which is regulated through transcriptional regulation of MUC2 expression is influenced with increased MUC2 transcription by multiple of factors. These factors are only expressed when the metabolic output of resident bacteria dominate the prebiotic effects on total microbiome composition (Hibberd et al., 2019). During inflammation, mucin glycosylation alters the influences of cytokines production and hormones (Hooper, 2010). Lipopolysaccharide (LPS) and lipoteichoic acid; interleukin (IL)-4 and IL-13; and vasoactive intestinal peptide hormone and cytokines such as tumor necrosis factors (TNF) all increase MUC2 transcription (SorgJA, 2008; Carter and Rood, 2012). The expression of the fucosyltransferase 2 (FUT2) in the intestine that accelerates fucosylation of intestinal mucins is induced by LPS and cytokine IL-23 (Van Maele et al. 2010). Once the changes in glycosylation are effected, the supply of carbohydrates for bacterial utilizing mucin glycans as the only source of carbon is equally 
obstructed; dysbiosis in the gut microbiota is the resulting consequences (Qiu et al., 2020a, b). An increased concentration of free fucose in the colon gives rise to Locus of Enterocyte Effacement (LEE) virulence genes produced by enterohaemorrhagic $E$. coli (Wells et al. 2011).

Once the gut bacterial composition is distorted, the bacterial diversity is lost. Extinction in number of species results in (Bajinka et al. 2020). Normalizing these diversities is not an easy intervention. One instance is seen in the intestinal mucus layer. It requires long-term microbial re-colonization (Hooper 2009). Gel-forming mucins are packed in the lumen for forming mucus wall. This layer is divided into inner firm and outer loose layer. While the former forms a coat for segregating microbes, the latter provides habitat for residence. Both play a role in penetration of mucosal integrity by bacteria. This dense impermeability of the inner layer enables the layer to be virtually sterile (Justesen et al. 1984). However, just as the national border chaos, mucin proteins, which are produced by the enormous rich and diverse O-glycans, will supply energy. In addition, they provide preferential binding sites for the commensal bacteria against pathogens (Kim and Ho, 2010) (Table 1). Unlike in the lumen, where species display is reduced, the outer mucus layer is a complex and unique niche. It shows a very organized bacterial species displaying different patterns of proliferation and utilization of resources. In the Golgi apparatus, glycosyltransferases is expressed and this determined the type of O-glycosylation. Any little changes in this complex will have an effect on the gut microbiota (Kim et al. 2014; Theriot et al. 2014). Two of the key proteins that are crucial in shaping the microbiota and hence mediating a normal health conditions are mucin glycosylation and mucus. These enable the selection of the highly microbial species to mediate host health.

\section{Epithelial microvilli and tight junction (TJ)}

On each of the thousands of microvilli, the epithelial harbors enterocytes. They form the brush border. The microvilli facilitate absorption of nutrients and defense luminal microbes, thereby restricting microbial adhesion.

Table 1 Bacterial mucosal receptors

\begin{tabular}{|c|c|c|c|}
\hline $\begin{array}{l}\text { Bacterial mucosal } \\
\text { receptors }\end{array}$ & Observations in the gut & Physiological changes in the gut & $\begin{array}{l}\text { Alternative remedies or } \\
\text { mechanisms }\end{array}$ \\
\hline $\begin{array}{l}\text { E. coli binding to Neu5Gc- } \\
\text { containing glycans }\end{array}$ & $\begin{array}{l}\text { Influence the gut microbiota population } \\
\text { and metabolism. }\end{array}$ & $\begin{array}{l}\text { Cause stomach disorders } \\
\text { (Sreevalsan and Safe, 2013) and loss } \\
\text { of short chain fatty acids (SCFAs). }\end{array}$ & $\begin{array}{l}\text { Diet rich in fibre promotes the } \\
\text { growth of bacteria that generate } \\
\text { SCFAs. }\end{array}$ \\
\hline $\begin{array}{l}\text { Changes in mucosal } \\
\text { glycosylation (due to } \\
\text { inflammation) }\end{array}$ & $\begin{array}{l}\text { Affects a low number among } \\
\text { bacteriophages and less eradicating } \\
\text { effects on bacteria specific for mucus- } \\
\text { penetrating (Kamada et al., 2013). }\end{array}$ & $\begin{array}{l}\text { The resulting dysbiosis is associated } \\
\text { with intestinal permeability (Kamada } \\
\text { et al., 2013). }\end{array}$ & $\begin{array}{l}\text { Akkermansia muciniphila is a } \\
\text { promising probiotics, improving } \\
\text { metabolic functions and immune } \\
\text { response (Zhang et al., 2019) }\end{array}$ \\
\hline $\begin{array}{l}\text { Increased free fucose in the } \\
\text { colon }\end{array}$ & $\begin{array}{l}\text { Confers locus of Enterocyte Effacement } \\
\text { (LEE) virulence genes produced by } \\
\text { Enterohaemorrhagic E.coli (Wells et al., } \\
\text { 2011). }\end{array}$ & $\begin{array}{l}\text { LEE effacing lesion, leading to a } \\
\text { brush border or lumen and } \\
\text { microvili destruction, loss of ion and } \\
\text { induce severe diarrhea. }\end{array}$ & $\begin{array}{l}\text { Eat diet rich in fibre to supply SCFAs } \\
\text { and fermented food to heal the gut. }\end{array}$ \\
\hline $\begin{array}{l}\text { Thinner mucus in the distal } \\
\text { colon (diet with Microbiota- } \\
\text { accessible carbohydrates } \\
\text { (MACs depletion) }\end{array}$ & $\begin{array}{l}\text { Increases the proximity of microbes to } \\
\text { the epithelium. }\end{array}$ & $\begin{array}{l}\text { The expression of an } \\
\text { inflammation marker REGIII } \beta \text { is } \\
\text { increased (Gebhart et al., 2015). }\end{array}$ & $\begin{array}{l}\text { Faecalibacterium prausnitzii has anti- } \\
\text { inflammatory effects partially via the } \\
\text { elevation of IL-10 production (Yan } \\
\text { et al., 2008). } \\
\text { TGF- } \beta \text { also suppresses an } \\
\text { inflammatory response and mediates } \\
\text { immune tolerance (Hornung et al., } \\
\text { 2009). }\end{array}$ \\
\hline $\begin{array}{l}\text { Shiga, bacterial toxins of type } \\
\text { AB5 and pertussis toxins }\end{array}$ & $\begin{array}{l}\text { Get adhered to the surface of intestinal } \\
\text { glycan (Sreevalsan and Safe, 2013). }\end{array}$ & $\begin{array}{l}\text { Influence the gut microbiota } \\
\text { population and metabolism. } \\
\text { Eventually cause stomach disorders } \\
\text { (Sreevalsan and Safe, 2013). }\end{array}$ & $\begin{array}{l}\text { Akkermansia muciniphila is a } \\
\text { promising probiotic, improving } \\
\text { metabolic functions and immune } \\
\text { response (Zhang et al., 2019) }\end{array}$ \\
\hline $\begin{array}{l}\text { Monosaccharide (from } \\
\text { intestinal glycans) }\end{array}$ & $\begin{array}{l}\text { Utilized by bacteria devoid of } \\
\text { glycosidases. }\end{array}$ & $\begin{array}{l}\text { Mediate a strong proliferating } \\
\text { response leading to dysbiosis } \\
\text { (Rahman et al., 2016). }\end{array}$ & Same intervention as above. \\
\hline $\begin{array}{l}\text { Obstructed mucin } \\
\text { glycosylation }\end{array}$ & $\begin{array}{l}\text { Obstruction of carbohydrates for } \\
\text { bacterial utilizing mucinglycans as source } \\
\text { of carbon (Rahman et al., 2016) }\end{array}$ & $\begin{array}{l}\text { Dysbiosis in the gut } \\
\text { microbiota is the resulting } \\
\text { consequences. }\end{array}$ & Same intervention as above. \\
\hline $\begin{array}{l}\text { The junctional adhesion } \\
\text { molecule A (JAM-A) } \\
\text { knockout }\end{array}$ & $\begin{array}{l}\text { Increase of Desulfovibrionaceae and } \\
\text { decrease of Akkermansia (Kashiwagi } \\
\text { et al., 2015) }\end{array}$ & $\begin{array}{l}\text { Wound-induced inflammation and } \\
\text { angiogenesis. }\end{array}$ & $\begin{array}{l}\text { Probiotics, dietary fiber, antioxidants, } \\
\text { mucosal nutrients stimulating } \\
\text { digestive enzymes. }\end{array}$ \\
\hline
\end{tabular}


Mucosa-associated microbes are repelled by the negative charge on the luminal surface of the epithelial microvilli and shapes gut microbiota (Chan et al. 2013). The exact phyla mediating this mechanism, causing alteration or the diversity of gut microbiota is yet to be studied.

The physical barrier consists of epithelial cells. These form intercellular TJs that check passage of the digested food and gut microbes to the deeper tissues. Paracellular permeability in the host is decreased with the help of gut commensal that can induce $\mathrm{TJ}$ protein expressions. However, in contrast to this positive effect, TJs are studied to be degraded by the decreased paracellular permeability conferred by the gut commensal. $\mathrm{TJ}$ proteins are internalized when disrupted via instigating the enterocytes. The molecular pathway of this process is not thoroughly studied. However, it is more likely the cause of luminal microbes to activate immunocytes in the lamina propria that shapes the microbiota (Hammer et al. 2014)

\section{Immune factors}

A non-inflammatory homeostasis involves mechanisms such as the secretion of anti-microbial proteins by the host cells, immunoglobulin A, and adequate mucus barrier as adherence to the epithelium. This ensures a symbiotic relationship between commensal in the gut (McGovern et al. 2010). In the absences of immunoglobulin-A, the immune system is studied to be associated with an increase in abundance of anaerobic bacteria in the gut. This includes mucosa-adherent segmented filamentous bacteria (SFB) from the phylum Firmicutes. Furthermore, components of the innate immune system affect gut microbiota. The inflammasome are all studied to be affecting the gut microbes (Table 2) (Zhu et al. 2017).

\section{Innate immunity}

Innate immunity of gut epithelium harbors enterocytes that express pattern recognition receptors (PRRs). PRRs sense microbes-associated molecular patterns (MAMPs) and promote the production of anti-microbial peptides, recruitment of immune cells and transportation of sIgAs as immune response (Liu et al. 2020). Various PRRs determine the sensing-response system of the host. The following will be looked into with respect to shaping the gut microbiota.

Toll-like receptors (TLRs), C-type lectin-like receptors (CLRs) and nucleotide-binding oligomerization domain (NOD)-like receptors (NLRs) forms of PPRs are critically recapitulated (Salzman et al., 2010). Dysbiosis-associated obesity and insulin resistance are prominent but only if there is an inactivation of the pattern recognition receptor (PPRs) that recognize flagellin on the epithelial surface. TLR5 helps to maintain the balance of microbiota by stimulating IL- 8 and TNF $\alpha$ in the epithelium and monocytes (Wells et al. 2011). They also induce the expression of IL-22 and IL-17 in the mucosa (Wehkamp et al. 2005). Much evidence arises from the mouse study. The microbial transfer of TLR5-deficient mice to wild type develops forms of metabolic syndromes. Blossoms of $E$. coli are seen with TLR5 deficiency in the intestine (Kumar et al. 2016).

In the terminal ileum, NOD2 receptor expressed monocytes and Paneth cells. It restricts colonization of pathogens and checked the number of bacteria to reside as commensal gut community (Sakaguchi et al. 2008). However, a polymorphisms occurring in the NOD2 gene during the stages of Crohn's disease (CD) lower the expression of $\alpha$-defensin in Paneth cells (Sokol et al. 2008). This is not good news for the gut community since loss of $\alpha$-defensin promotes the increasing ratio of Firmicutes to Bacteriodetes. This in turn promotes the growth of SFB that initiate antimicrobial defense. Furthermore, expansion of SFB is inhibited with an increase in $\alpha$ defensin expression of IL-17. Low number of IL-17producing Th17 cells in the lamina propria signals loss of $\alpha$-defensin and expansion of SFB (Elinav et al. 2011).

Treg cells are regulatory $\mathrm{T}$ cells that secrete antiinflammatory IL-10.They also transform growth factor TGF- $\beta$ that ensures mutualism relationship with the microbiota (Irrazábal et al., 2014). A reduced IL-10 from the mouse study was associated with an increased abundance of Bacteriodetes, Proteobacteria, and Verrucomicrobia. Inflammation in the caecum and colon is prominent due to this shift. One such bacterium from Proteobacteria is E. coli, seen with 100 -fold increased (Arthur et al., 2012). Again E. coli are enriched in the absence of dendritic cells-specific (DC-specific) TGF- $\beta$ signaling. Note TGF- $\beta$ mediates immune tolerance by suppressing an inflammatory response. In addition to its occurring in Treg cells, it occurs in DC and other cells of intestinal mucosa (Wells et al. 2011).

\section{Secretory $\lg A(\operatorname{sg} A)$}

Plasma cells in the lamina propria of gut produce IgA that is transported through the enterocytes into the lumen. The outermost layer harbors mucins and bacteria that interact with sIgA. Changes in gut microbiota are studied to be associated with reduction of sIgA levels in Rig-1 and lymphotoxin (LT)- $\alpha$ knockout mouse (Fadlallah et al. 2018). Bacteria-binding capacities that induce alteration in microbiota are reduced with the sIgAs inhibitory co-receptor programmed cell death-1 (PD-1) knockout mice. Establishing the role of the sIgAs in shaping gut microbiota and control of gut ecology homeostasis, individuals with IgA deficiency are as well studied to have alteration of gut microbiota (van den Elsen et al. 2019). Both the breast milk-derived sIgA and sIgA- 
Table 2 Immune factors influencing gut microbes

\begin{tabular}{|c|c|c|c|}
\hline Immunity & Observations in the gut & Alteration in the gut & Alternative remedies or mechanisms \\
\hline $\begin{array}{l}\text { Absences of } \\
\text { immunoglobulin A }\end{array}$ & $\begin{array}{l}\text { Increase in mucosa-adherent seg- } \\
\text { mented filamentous bacteria (SFB) } \\
\text { from the phylum Firmicutes (Wells } \\
\text { et al. 2011). }\end{array}$ & $\begin{array}{l}\text { This is linked with autoimmune diseases } \\
\text { such as encephalitis and arthritis. }\end{array}$ & $\begin{array}{l}\text { Enriching the gut with genera such as } \\
\text { Eubacterium, Prevetolla and Roseburia(Qiu } \\
\text { et al., 2020a, b) }\end{array}$ \\
\hline $\begin{array}{l}\text { Absence of } \\
\text { dendritic cells- } \\
\text { specific (DC-spe- } \\
\text { cific) TGF- } \beta \\
\text { signaling }\end{array}$ & E. coli are enriched in the gut. & $\begin{array}{l}\text { Non mediation of immune tolerance and } \\
\text { inflammatory response is prominent (Wells } \\
\text { et al. 2011). }\end{array}$ & $\begin{array}{l}\text { The probiotic Clostridium butyricum is able } \\
\text { to induce TGF- } \beta \text { signaling in DC, which in } \\
\text { turn induces Treg cell generation (Hornung } \\
\text { et al. 2009). }\end{array}$ \\
\hline $\begin{array}{l}\text { Polymorphisms in } \\
\text { the NOD1 gene } \\
\text { and NOD2 gene }\end{array}$ & $\begin{array}{l}\text { Changes in the levels of } \\
\text { Enterobacteriaceae in humans } \\
\text { (Knights et al. 2014; Elinav et al. } \\
\text { 2011). }\end{array}$ & $\begin{array}{l}\text { The resulting dysbiosis is associated with } \\
\text { intestinal permeability and onset of } \\
\text { inflammation (Kamada et al. 2013). }\end{array}$ & $\begin{array}{l}\text { The knockout of resistant-like molecule } \beta \\
\text { (RELM } \beta \text { ) gives abundance of Bacteroidetes, } \\
\text { Firmicutes and Proteobacteria (Bonder et al. } \\
\text { 2016) and hence a healthy gut. }\end{array}$ \\
\hline $\begin{array}{l}\text { NOD2 knockout } \\
\text { mice }\end{array}$ & $\begin{array}{l}\text { Harbor a higher amount of } \\
\text { Bacteroides, } \\
\text { Firmicutes and } \\
\text { Bacillus in the terminal ileum }\end{array}$ & $\begin{array}{l}\text { Have downregulated expression of a- } \\
\text { defensins and were more susceptible to Lis- } \\
\text { teria monocytogenes infection (Dheer et al. } \\
\text { 2016). }\end{array}$ & $\begin{array}{l}\text { NLRP6 inflammasome deficient mice } \\
\text { increased Prevotellaceae and TM7, and } \\
\text { reductions of genus Lactobacillus in the } \\
\text { Firmicutes phylum (Kobayashi et al. 2005) }\end{array}$ \\
\hline $\begin{array}{l}\text { Mice with } \\
\text { intestinal } \\
\text { epithelium over } \\
\text { expression of TLR4 }\end{array}$ & $\begin{array}{l}\text { Abundance of } \\
\text { Fusobacteria and } \\
\text { Proteobacteria and } \\
\text { lower abundances of Firmicutes in } \\
\text { the colonic mucosa (Bereswill et al. } \\
\text { 2014) }\end{array}$ & $\begin{array}{l}\text { This condition is associated with the onset } \\
\text { of colorectal cancer. }\end{array}$ & $\begin{array}{l}\text { TLR2 in T cells has been proven to help the } \\
\text { colonization of commensal Bacteroides } \\
\text { fragilis in the gut (June et al., 2011). }\end{array}$ \\
\hline $\begin{array}{l}\text { TLR9 knockout } \\
\text { mice }\end{array}$ & $\begin{array}{l}\text { Lower Enterobacteria and } \\
\text { Bacteroidetes, whereas levels of } \\
\text { Clostridium leptum and } \\
\text { Bifidobacteria expand (Xiao et al. } \\
\text { 2019). }\end{array}$ & $\begin{array}{l}\text { Increased prevalence of IgG2a and } \\
\text { accelerated renal diseases (Albert et al. } \\
\text { 2009). }\end{array}$ & $\begin{array}{l}\text { Increase Firmicutes and Proteobacteria } \\
\text { associated with higher level of miR-200a-3p } \\
\text { (Johansson et al. 2011). }\end{array}$ \\
\hline $\begin{array}{l}\text { Mice deficient in } \\
\text { TLR5 }\end{array}$ & $\begin{array}{l}\text { Higher abundance in Bacteroidetes } \\
\text { and Lachnospiraceae (Suzuki et al. } \\
\text { 2004) }\end{array}$ & $\begin{array}{l}\text { Spontaneous intestinal inflammation and } \\
\text { metabolic abnormalities, however not much } \\
\text { evidence. }\end{array}$ & $\begin{array}{l}\text { TLR4 knockout in mice decreased the } \\
\text { abundance of Bacteroidetes (Suzuki et al., } \\
\text { 2004), The mice lacking matrix } \\
\text { metalloproteinase 7; (MMP7 displayed a } \\
\text { significantly higher abundances of } \\
\text { Firmicutes and a significantly lower } \\
\text { abundances of Bacteroidetes (Mathias et al. } \\
\text { 2010). }\end{array}$ \\
\hline $\begin{array}{l}\text { Inactivation of } \\
\text { NLRP6 proteins }\end{array}$ & $\begin{array}{l}\text { NLRP-6-deficiency affects the goblet } \\
\text { cells in }\end{array}$ & $\begin{array}{l}\text { Reduced mucus layer thereby enabling } \\
\text { microbes to be more susceptible to dextran } \\
\text { sulfate sodium-induced colitis and some } \\
\text { forms of intestinal infections (Hooper, 2010). }\end{array}$ & $\begin{array}{l}\text { TLR2 in T cells has been proven to help the } \\
\text { colonization of commensal Bacteroides } \\
\text { fragilis in the gut (June et al., 2011). }\end{array}$ \\
\hline NLRP6 protein & $\begin{array}{l}\text { Mediates IL-18 secretion via } \\
\text { caspase-1 }\end{array}$ & $\begin{array}{l}\text { A pro-inflammatory cytokine that suppresses } \\
\text { mucin production and promote ulcerative } \\
\text { colitis among the type colitis (Hu et al. } \\
\text { 2015). }\end{array}$ & $\begin{array}{l}\text { IL-22-binding protein express antimicrobial } \\
\text { peptides and induce tissue repair (Wells } \\
\text { et al. 2011), hence playing an important } \\
\text { function in intestinal homeostatic (Wang } \\
\text { et al. 2014). }\end{array}$ \\
\hline RIG-1 knockout & $\begin{array}{l}\text { Altered microbiota in comparison } \\
\text { with wild-type mice. }\end{array}$ & $\begin{array}{l}\text { Microbial change could be linked to the } \\
\text { downregulation of IgA, REGIlly, and PD-1 } \\
\text { (Schroeder et al. 2011). }\end{array}$ & $\begin{array}{l}\text { AIM2 mediation of antimicrobial peptides } \\
\text { such as C-type lectins (REGIII } \beta \text { and REGIII } \gamma \text { ), } \\
\text { calprotectin (S100A8 and S100A9) and lipo- } \\
\text { calin } 2 \text { (Lcn2) in gut epithelial cells (Schnee- } \\
\text { berger et al. 2018). }\end{array}$ \\
\hline $\begin{array}{l}\text { B-defensins, such } \\
\text { as DEFB1, beta- } \\
\text { defensin } 1 \\
\text { (DEFB1) }\end{array}$ & $\begin{array}{l}\text { Bactericidal effects against the } \\
\text { gram-positive commensal of Bifido- } \\
\text { bacterium and Lactobacillus (Mathias } \\
\text { et al. 2010). }\end{array}$ & $\begin{array}{l}\text { Reduction in mucosal microbial community } \\
\text { and likelihood of onset of insulin resistance. }\end{array}$ & $\begin{array}{l}\text { Immunoglobulin receptor (plgR), CD71, and } \\
\text { CD89 on the epithelial cells may enable } \\
\text { microbes to benefit from slgA to build up a } \\
\text { mucosal microbial community (Mathias } \\
\text { et al. 2010; Vangay et al. 2018). }\end{array}$ \\
\hline
\end{tabular}

coated bacteria have demonstrated sIgAs binding affinity with gut bacteria. While the former helps in shaping the gut microbiota, the latter is found with protective effects on mice from diseases (Gersemann et al. 2009).

\section{Inflammasome}

TM7 bacteria (Saccharibacteria) and Pretovella spp.are expanded when the inflammasome complex NOD-like receptor family of pyrin domain containing NLRP6 proteins is inactivated (Davis, 1974). The goblet cells in 
NLRP-6-deficiency from the mouse model of study confer a reduced mucus layer. This enables microbes to be more susceptible to dextran sulfate sodium-induced colitis causing intestinal infections (Kashiwagi et al. 2015). NLRP6 mediates IL-18 secretion via caspase-1. The exact role that IL-18 is playing in the intestinal homeostasis is not established. However, some studies on mouse model found it as a pro-inflammatory cytokine that suppresses mucin production. The mechanism is by inhibiting the maturation of goblet cells that protect and maintain mucus blanket through synthesizing mucin. In doing this, it promotes ulcerative colitis among the type colitis (McGovern et al. 2010). However, IL-22-binding protein is also studied to be induced by IL-18 through down regulating inflammasome. This protein will express antimicrobial peptides and induce tissue. Hence, playing an important function in intestinal homeostatic (Gebhart et al. 2015).

In addition, the presence and absences of $\mathrm{H}$ and $\mathrm{ABO}$ antigens in GI mucosa that is determined by the FUT2 genotype directly affects bacterial diversity. Remember FUT2 genotype is a gene expressing $\alpha 1$, 2fucosyltransferase (Neu and Walker 2011). Also in some books, the presence and absence of $\mathrm{H}$ and $\mathrm{ABO}$ antigens will be found as 'secretor and non-secretor.' In one of studies using mouse model, diet with MACs depletion showed thinner mucus in the distal colon. This increases the proximity of microbes to the epithelium and the expression of an inflammation marker REGIII $\beta$ is heightened (Gebhart et al. 2015). The heightening of inflammation marker REGIII $\beta$ means regenerating gene family protein 3 , lectins belonging to the antimicrobial proteins. This leads to alteration of gut microbiota.

\section{Host secretions \\ Glycans}

Bacteriodetes, when expanded inside the gut, signal increased carbohydrate-fermenting machineries such as hydrolase enzymes and transporters. These utilize monosaccharide as the carbon source (Vuille-dit-Bille et al., 2015). Bacteriodetes and some Firmicutes, such as Ruminococcus gnavus, Ruminococcus flavefaciens, Ruminococcus intestinalis, and Akkermansia muciniphila from Phylum Verrucomicroiota enable microbes to possess greater ability to extract carbohydrates from mucin glycans (Srinivasjois et al. 2013; Carter and Rood, 2012). When Enterobacteriaceae lost the enzymatic ability to degrade intestinal mucins, Bifidobacterium spp, which is prominent in the infant gut from breast milk ferments complex fucosylated oligosaccharides (Lawson et al., 2020). These can reduce pathogen adhesion to the gut by serving as decoy receptors, thus protecting infants (Kelly et al., 1994).
The differences in carbohydrate composition in the intestinal mucosa orient the various binding domains of bacterial species. Some of the adhesions earlier studied as binding domains to the intestinal glycans are but not limited to fimbriae, pili, and adhesins. While the pathogen Campylobacter jejuni express binding mechanism to fucosylated epitopes (blood group antigens H2, Lewis-b, Lewis-y and Lewis-x (Van Maele et al. 2010), another commensal in the gut such as Lactobacilli depend on mucus-binding proteins to colonize the gastrointestinal (GI) tract (Toyoda et al. 2015). In essence, the oligosaccharides found in human milk give higher density of fucosylated glycan in the lumen of the intestine and the inhibition to the adherence of $C$. jejuni. The binding specificity of E. coli $\mathrm{K} 99$ utilizes fimbriae as the domain of adhesion. This enables the bacteria to recognize gangliosides terminated with 2,3-linked NEu5Gc (Oliver et al. 2003). This is one of the ways in which intestinal glycans can regulate the binding mechanisms of the microbes in the gut. Strict consumption of red meat means gut rich in Neu5Gc. Since human cells cannot digest this, the SubAB toxin secreted by Shiga toxigenic E. coli use this opportunity and bind to Neu5Gc-containing glycans on human epithelial cells. Although the mechanisms are not studied at length, other toxins like cholera, Shiga, bacterial toxins of type AB5, and pertussis toxins all get adhered to the surface of intestinal glycans. They influence the gut microbiota population, metabolism, and eventually cause stomach disorders (Sreevalsan and Safe 2013).

Bacteriophages, which are virus that infect bacteria, help to control the number of mucus-penetrating bacteria through intestinal glycoprotein, which favors its higher density. In turn, they serve as a protective barrier for the host (Sokol et al. 2008). However, any changes in mucosal glycosylation due to inflammation affect a low number among bacteriophages. This means less eradicating effects on bacteria specific for mucus-penetration (Kamada et al. 2013). The resulting dysbiosis is also considered to be associated with intestinal permeability. Intestinal glycans are reviewed to be self-regulated for glycosylation and mucin secretion. The factors apart from the adhesion specificity, diet, and genes also increase the risk of diseases and hence dysbiosis. In fact, hypomorphic alleles expresses 1-2-fucosyltransferase FUT2 enzyme that is known to be associated with CD (Kuper, 2000).

\section{Bile acids}

Bile acids taurocholate and deoxycholate, secreted by gall bladder in the duodenum facilitates the germination of $C$. difficile (Liu et al. 2016). While the mechanism in which gut with its resilient effects suppress the vegetative growth of $C$. difficile in asymptomatic patients 
remain elusive, competition for $\mathrm{N}$-acetylglucosamine and Neu5Ac carbohydrate derived from intestinal mucins are established (Sakaguchi et al. 2008). Exhausting these nutrients is a means to stop the over growth of $C$. difficile. The competition to stop the overgrowth of $C$. difficile goes beyond depriving nutrients. Some microbes have the potential to transform the bile acids that would not favor the proliferation of $C$. dificile. With this, there will be no germination of clostridia spores in the gut (Srinivasjois et al. 2013).

\section{Discussion}

As humans require shelter to live a healthy life, so do the microbes. Microbes have the ability to shape and maintain their composition in a way to confer protections against any environmental selective pressures. These pressures might be external stimuli or internal aggression of combined microbial and cell physiology. The borderline controllers of our gut microbiota ensure that anything foreign to the body is screened at microscopic level, non-threat to the body and be physiologically symbiotic with the normal intestinal microbes. They do this by recruiting and using the host immune system and establishing a multi-factorial and dynamic intestinal barrier. It is interesting enough to know that the multifactorial intestinal barrier consists of immunological (Immunoglobulin A (IgA) and epithelia-associated immune cells), physical (mucus layers and the epithelial), and biochemical (enzymes and antimicrobial proteins) factors influence the balance of micro-organisms in the gut (Frank et al. 2007).
IgA being the principal antibody plays a crucial role in the immune functioning of mucosal membrane. It is the first line of defense mediating a variety of protective functions via the interaction with specific receptors and immune mediators. The intrinsic factors range from the $\mathrm{pH}$ of the intestine, host body temperature, and microbial interactions. In addition, physiological factors will be host secretions and immune response, bile acids, peristalsis and bacterial mucosal receptors (Lachnit et al. 2019). Gut as a complex organ composed of multilayer of tissues in shaping microbiota. It consists of epithelia that serve as the frontline in response to both direct and indirect response to luminal microbes. Epitheliumassociated factors on gut microbes include epithelial tight junctions, epithelial microvilli, epithelial innate immune sensors, mucus barrier, epithelial metabolism, slgAs, oxygen barrier, and microRNA. Description of the physiological factors influencing gut microbes, immediate consequences is worth exploring (Fig. 1).

Exogenous factor such as diet, antibiotics, and other used drugs while eliminating their targeted pathogens, will as well wash away number of commensal organisms. This gives chances for resistance pathogens to overgrow, consequently comprising of the pathobionts. The interplay of these pathobionts and dysbiotic community functionalities determine the pathogenic potential, called nososymbiocity. The host-microbes interplay and communicate through a space provided by the mucus layer. This is possible since epithelial cells composed of mucins/epithelial glycocalyx and secreted gel-forming mucins/mucus wall. Without the host physiological factors that include immune response and secretions due to the

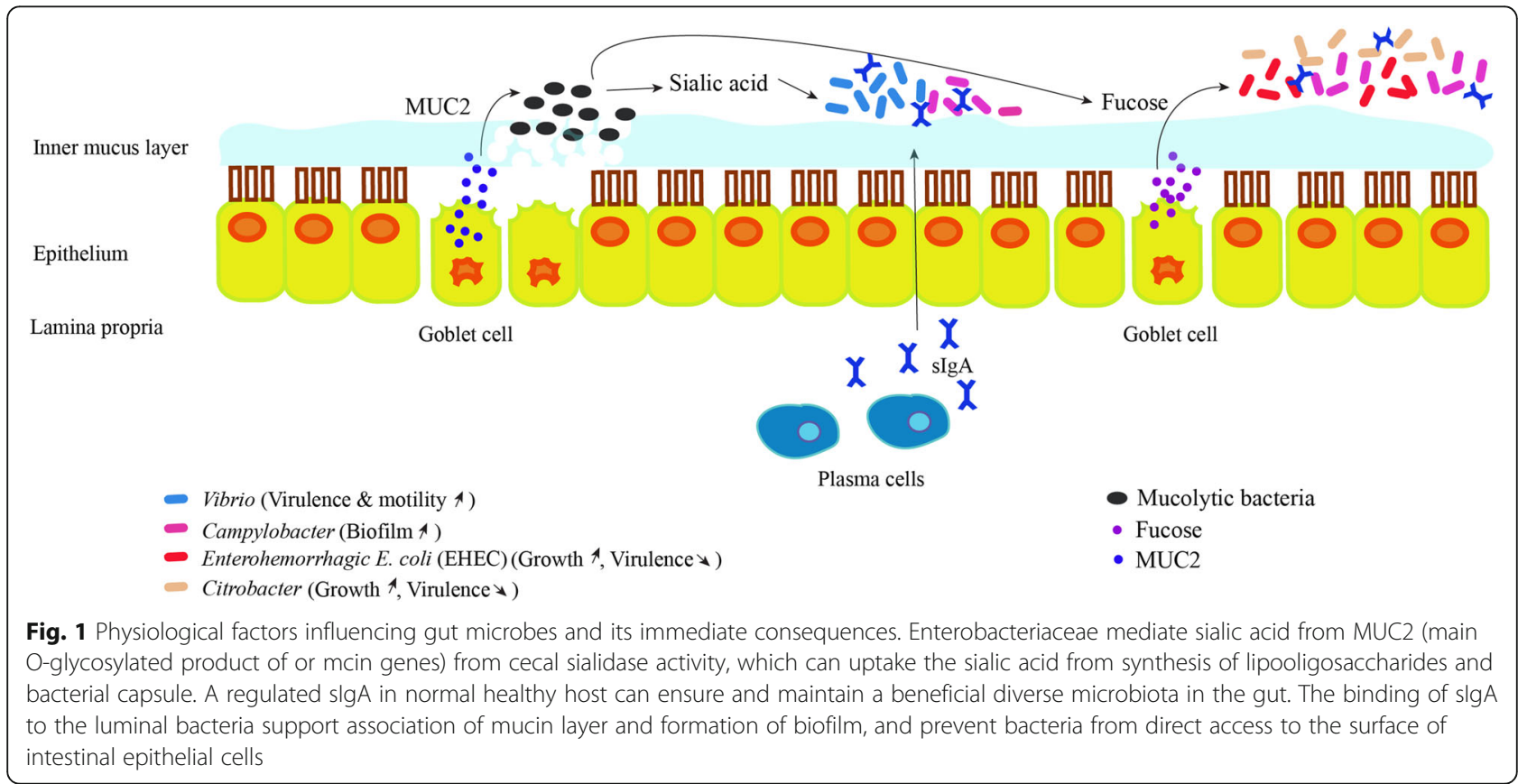


resilient homeostasis of the gut, inflammation and other diseases will be prominent among gut microbiota harboring organisms.

\section{Conclusion}

The physiological factors suppress these pathobionts and mediate gut recovery in respect to healthy gut by stabilizing the increased pro-inflammatory potential with the help of cell barriers, host secretions and immune response. The effective adaptive immune response that serves as defense and regulation of immune responses and inflammation does this by determining what will pass through the gut. The cells doing these tasks are epithelia-associated cells found in the lining of epithelium. Although first line defense against pathogens are provided by the innate immunity comprises antimicrobial peptides and proteins, the disruptive functions of microbial cells against pathogenic bacteria requires multiple and careful design of studies.

\section{Abbreviations \\ CD: Crohn's disease; CLRS: C-type lectin-like receptors; DEFB1: Beta-defensin 1; DC-specific: Dendritic cells-specific; FMT: Fecal microbiota transplantation; FUT2: Fucosyltransferase 2; GALT: Gut-associated lymphatic tissue; GI: Gastrointestinal; IgA: Immunoglobulin A; LEE: Locus of enterocyte effacement; LPS: Lipopolysaccharide; LT: Lymphotoxin; MAC: Microbiota- accessible carbohydrates; MAMPs: Microbes-associated molecular patterns; MMP7: Matrix metalloproteinase 7; NOD: Nucleotide-binding oligomerization domain; PRRs: Pattern recognition receptors; PD-1: Programmed cell death-1; slgA: Secretory A; SFB: Segmented filamentous bacteria; TJ: Tight junction; TNF: Tumor necrosis factors; TLRs: Toll-like receptors}

\section{Acknowledgements}

Not applicable

\section{Authors' contributions}

OB wrote the manuscript. YT, KAA, LBC, and AD edited and reviewed the paper. The author(s) read and approved the final manuscript.

\section{Funding}

This work was supported by Grant 31670121 and 31771277 from National Natural Science Foundation of China.

\section{Availability of data and materials}

Not applicable

\section{Ethics approval and consent to participate}

Not applicable

\section{Consent for publication}

Not applicable

\section{Competing interests}

The authors declare no competing interest.

\section{Author details}

'Department of Microbiology, Central South University, Changsha, Hunan Provinces, China. ${ }^{2}$ China-Africa Research Centre of Infectious Diseases, School of Basic Medical Sciences, Central South University, Changsha 410078, Hunan, China. ${ }^{3}$ Vaccine \& Immunity Theme, Infant Immunology, Medical Research Council Unit, The Gambia at London School of Hygiene \& Tropical Medicine (MRCG@LSHTM), London, England. ${ }^{4}$ Medical Research Council Unit, The Gambia at London School of Hygiene \& Tropical Medicine (MRCG@LSHTM), London, England. ${ }^{5}$ Faculty of Science, Department of
Biology, Section of Basic and Industrial Microbiology, Ege University, Izmir, Turkey. ${ }^{6}$ Institute of Immunology, University Hospital Essen, Essen, Germany.

Received: 3 July 2020 Accepted: 6 November 2020

Published online: 23 November 2020

\section{References}

Albert EJ, Sommerfeld K, Gophna S, Marshall JS (2009) GophnaU. The gut microbiota of toll-like receptor 2-deficient mice exhibits lineage-specific modifications. Environ Microbiol Rep 1(1):65-70

Arthur JC, Perez-Chanona E, Mühlbauer M, Tomkovich S, Uronis JM, Fan TJ, Campbell BJ, Abujamel T, Dogan B, Rogers AB, Rhodes JM, Stintzi A, Simpson KW, Hansen JJ, Keku TO, Fodor AA, Jobin C (2012) Intestinal inflammation targets cancer-inducing activity of the microbiota. Science 338(6103):120-123

Arumugam M, Raes J, Pelletier E et al (2011) Enterotypes of the human gut microbiome. Nature 473(7346):174-180

Bajinka O, Secka O (2017) Integration of molecular methods into microbiological diagnostics. Apply Micro Open Access 3:130

Bajinka O, Tan Y, Abdelhalim KA et al (2020) Extrinsic factors influencing gut microbes, the immediate consequences and restoring eubiosis. AMB Expr 10:130

Bereswill S, Kuhl AA, Alutis M et al (2014) The impact of toll-like-receptor-9 on intestinal microbiota composition and extra-intestinal sequelae in experimental toxoplasma gondii induced ileitis. Gut Pathog. 6:19

Bonder MJ, Kurilshikov A, Tigchelaar EF et al (2016) The effect of host genetics on the gut microbiome. Nat Genet 48(11):1407-1412

Carter GP, Rood II (2012) LyrasD.The role of toxin A and toxin B in the virulence of Clostridium difficile. Trends Microbiol 20(1):21-29

Chan YK, Estaki M, Gibson DL (2013) Gibson. Clinical consequences of dietinduced dysbiosis. Ann NutrMetab 63(suppl 2):28-40

Davis CP (1974) SavageDC. Habitat, succession, attachment, and morphology of segmented, filamentous microbes indigenous to the murine gastrointestinal tract. Infect Immun 10(4):948-956

Dheer R, Santaolalla R, Davies JM, Lang JK, Phillips MC, Pastorini C (2016) Intestinal epithelial toll-like receptor 4 signaling affects epithelial function and colonic microbiota and promotes a risk for transmissible colitis. Infect Immun 84(3):798-810

Elinav E, Strowig T, Kau AL et al (2011) NLRP6 inflammasome regulates colonic microbial ecology and risk for colitis. Cell 145(5):745-757

Fadlallah J, El Kafsi H, Sterlin D et al (2018) Microbial ecology perturbation in human IgA deficiency. SciTransl Med 10(439):eaan1217

Frank DN, St Amand AL, Feldman RA, Boedeker EC, Harpaz N, Pace NR (2007) Molecular-phylogenetic characterization of microbial community imbalances in human inflammatory bowel diseases. ProcNatIAcadSci USA 104:1378013785

Gebhart D, Lok S, Clare S et al (2015) A modified R-type bacteriocin specifically targeting Clostridium dificile prevents colonization of mice without affecting gut microbiota diversity. MBio 6(2)

Gersemann M, Becker S, Kübler I et al (2009) Differences in goblet cell differentiation between Crohn's disease and ulcerative colitis. Differentiation. 77(1):84-94

Hammer TJ, McMillan WO, Fierer N (2014) Metamorphosis of a butterflyassociated bacterial community. PLoSONE 9(1):e86995

Hibberd AA, Yde CC, Ziegler ML et al (2019) Probiotic or synbiotic alters the gut microbiota and metabolism in a randomised controlled trial of weight management in overweight adults. Benef Microbes 10(2):121-135

Hooper LV (2009) Do symbiotic bacteria subvert host immunity? Nat Rev Microbiol 7:367-374

Hooper LV (2010) MacphersonAJ. Immune adaptations that maintain homeostasis with the intestinal microbiota. Nat Rev Immunol 10(3):159-169

Hornung V, Ablasser A, Charrel-Dennis M et al (2009) AIM2 recognizes cytosolic dsDNA and forms a caspase-1-activating inflammasome with ASC. Nature 458(7237):514-518

Hu S, Peng L, Kwak YT et al (2015) The DNA sensor AIM2 maintains intestinal homeostasis via regulation of epithelial antimicrobial host defense. Cell Rep 13(9):1922-1936

Irrazábal T, Belcheva A, Girardin SE, Martin A, Philpott DJ (2014) The multifaceted role of the intestinal microbiota in colon cancer. Mol Cell 54(2):309-320

Johansson ME, Larsson JM, Hansson GC (2011) The two mucus layers of colon are organized by the MUC2 mucin, whereas the outer layer is a legislator of host-microbial interactions. ProcNatlAcadSci USA 108(Suppl 1):4659-4665 
June L, Round S, Lee M, Li J, Tran G, Jabri B (2011) The toll-like receptor 2 pathway establishes colonization by a commensal of the human microbiota. Science 332(6032):974-977

Justesen T, Nielsen OH, Jacobsen IE, Lave J, Rasmussen SN (1984) The normal cultivable microflora in upper jejunal fluid in healthy adults. Scand J Gastroenterol 19:279-282

Kamada N, Seo SU, Chen GY, Núñez G (2013) Role of the gut microbiota in immunity and inflammatory disease. Nat Rev Immunol 13(5):321-335

Kasai C, Sugimoto K, Moritani I et al (2015) Comparison of the gut microbiota composition between obese and non-obese individuals in a Japanese population, as analyzed by terminal restriction fragment length polymorphism and next-generation sequencing. BMC Gastroenterol 15:100

Kashiwagi I, Morita R, Schichita T et al (2015) Smad2 and Smad3 inversely regulate TGF- $\beta$ Autoinduction in Clostridium butyricum-Activated Dendritic Cells. Immunity 43(1):65-79

Kelly CP, Becker S, Linevsky JK et al (1994) Neutrophil recruitment in Clostridium difficile toxin A enteritis in the rabbit. J Clin Invest 93(3):1257-1265

Kim HY, Lee HJ, Chang YJ et al (2014) Interleukin-17-producing innate lymphoid cells and the NLRP3 inflammasome facilitate obesity-associated airway hyperreactivity. Nat Med 20(1):54-61

Kim YS, Ho SB (2010) Intestinal goblet cells and mucins in health and disease: recent insights and progress. CurrGastroenterol Rep 12(5):319-330

Knights D, Silverberg MS, Weersma RK et al (2014) Complex host genetics influence the microbiome in inflammatory bowel disease. Genome Med 6(12):107

Kobayashi KS, Chamaillard M, Ogura Y et al (2005) Nod2-dependent regulation of innate and adaptive immunity in the intestinal tract. Science 307(5710):731-734

Kumar P, Monin L, Castillo P et al (2016) Intestinal interleukin-17 receptor signaling mediates reciprocal control of the gut microbiota and autoimmune inflammation. Immunity 44(3):659-671

Kuper H, Adami HO, Trichopoulos D (2000) Infections as a major preventable cause of human cancer. J Intern Med 248(3):171-183

Lachnit T, Bosch TCG, Deines P (2019) Exposure of the host-associated microbiome to nutrient-rich conditions may lead to dysbiosis and disease development-an evolutionary perspective. mBio 10:e00355-e00319

Lawson MAE, O'Neill IJ, Kujawska M, GowrinadhJavvadi S, Wijeyesekera A, Flegg Z, Chalklen L, Hall LJ (2020) Breast milk-derived human milk oligosaccharides promote Bifidobacterium interactions within a single ecosystem. ISME J 14(2): 635-648

Ley RE, Lozupone CA, Hamady M, Knight R, Gordon Jl (2008) Worlds within worlds: evolution of the vertebrate gut microbiota. Nat Rev Microb 6:776-788

Liu D, Tan Y, Bajinka O, Wang L, Tang Z (2020) Th17/IL-17 axis regulated by airway microbes get involved in the development of asthma. Curr Allergy Asthma Rep 20(4):11

Liu S, da Cunha AP, Rezende RM et al (2016) The host shapes the gut microbiota via fecal MicroRNA. Cell Host Microbe 19(1):32-43

Marques TM, Wall R, Ross RP, Fitzgerald GF, Ryan CA, Stanton C (2010) Programming infant gut microbiota: influence of dietary and environmental factors. CurrOpinBiotechnol 21(2):149-156

Mathias A, Duc M, Favre L, Benyacoub J, Blum S, Corthesy B (2010) Potentiation of polarized intestinal Caco-2 cell responsiveness to probiotics complexed with secretory lgA. J Biol Chem 285(44):33906-33913

McGovern DP, Jones MR, Taylor KD et al (2010) Fucosyltransferase 2 (FUT2) nonsecretor status is associated with Crohn's disease. Hum Mol Genet 19(17): 3468-3476

Neu J, Walker WA (2011) Necrotizing enterocolitis. N Engl J Med 364(3):255-264

Oliver KM, Russell JA, Moran NA, Hunter MS (2003) Facultative bacterial symbionts in aphids confer resistance to parasitic wasps. ProcNatlAcadSciUSA 100:1803-1807

Qiu X, Bajinka O, Tan Y et al (2020b) Effects of high-fat diet on the epithelial mesenchymal transition of respiratory tract through the glyoxylic acid cycle of pulmonary microbes and the intervention of saturated hydrogen. J Biomedical Sci;Preprint. https://doi.org/10.21203/rs.3.rs-17519/v1

Qiu X, Ye Q, Sun M, Wang L, Tan Y, Wu G (2020a) Saturated hydrogen improves lipid metabolism disorders. Exp Biol Med 0:1-10

Rahman K, Desai C, lyer SS et al (2016) Loss of junctional adhesion molecule a promotes severe steatohepatitis in mice on a diet high in saturated fat, fructose, and cholesterol. Gastroenterology 151(4):733-746 e712

Saha JR, Butler VP, Neu HC, Lindenbaum J (1983) Digoxin-inactivating bacteria: identification in human gut microbiota. Science 220:325-327
Sakaguchi S, Yamaguchi T, Nomura T, Ono M (2008) Regulatory T cells and immune tolerance. Cell. 133(5):775-787

Salzman NH, Hung K, Haribhai D et al (2010) Enteric defensins are essential regulators of intestinal microbial ecology. Nat Immunol 11(1):76-83

Schneeberger K, Roth S, Nieuwenhuis EES, Middendorp S (2018) Intestinal epithelial cell polarity defects in disease: lessons from microvillus inclusion disease. Dis Model Mech 11(2):dmm031088

Schroeder BO, Wu Z, Nuding S et al (2011) Reduction of disulphide bonds unmasks potent antimicrobial activity of human beta-defensin 1. Nature 469(7330):419-423

Sokol H, Pigneur B, Watterlot $L$ et al (2008) Faecalibacterium prausnitzii is an antiinflammatory commensal bacterium identified by gut microbiota analysis of Crohn disease patients. ProcNatlAcadSci USA 105(43):16731-16736

SorgJA SAL (2008) Bile salts and glycine as cogerminants for Clostridium difficile spores. J Bacteriol 190(7):2505-2512

Sreevalsan S, Safe S (2013) Reactive oxygen species and colorectal cancer. Curr Colorectal Cancer Rep 9(4):350-357

Srinivasjois R, Rao S, Patole S (2013) Prebiotic supplementation in preterm neonates: updated systematic review and meta-analysis of randomised controlled trials. ClinNutr 32(6):958-965

Suzuki K, Meek B, Doi Y et al (2004) Aberrant expansion of segmented filamentous bacteria in IgA-deficient gut. ProcNat|AcadSci USA 101(7):1981-1986

Thaiss CA, Zmora N, Levy M, Elinav E (2016) The microbiome and innate immunity, Nature 535(7610):65-74

Theriot CM, Koenigsknecht MJ, Carlson PE Jr et al (2014) Antibiotic-induced shifts in the mouse gut microbiome and metabolome increase susceptibility to Clostridium dificile infection. NatCommun 5:3114

Toyoda M, Ogata Y, Mahiti M et al (2015) Differential Ability of Primary HIV-1 Nef Isolates To Downregulate HIV-1 Entry Receptors. J Virol 89(18):9639-9652

van den Elsen LWJ, Garssen J, Burcelin R, Verhasselt V (2019) Shaping the gut microbiota by breastfeeding: the gateway to allergy prevention? Front Pediatr 7:47

Van Maele L, Carnoy C, Cayet D et al (2010) TLR5 signaling stimulates the innate production of IL-17 and IL-22 by CD3(neg)CD127+ immune cells in spleen and mucosa. J Immunol 185(2):1177-1185

Vangay P, Johnson AJ, Ward TL et al (2018) US immigration Westernizes the human gut microbiome. Cell 175:962-972

Vuille-dit-Bille RN, Camargo SM, Emmenegger L et al (2015) Human intestine luminal ACE2 and amino acid transporter expression increased by ACEinhibitors. Amino Acids 47(4):693-705

Wang F, Mark Y, Sun S, Serena S, Zhun SL (2014) Helicobacter pylori infection and normal colorectal mucosa-adenomatous polyp-adenocarcinoma sequence: a meta-analysis of 27 case-control studies. Colorectal Dis 16(4): 246-252

Wehkamp J, Salzman NH, Porter E et al (2005) Reduced Paneth cell alphadefensins in ileal Crohn's disease. ProcNatlAcadSci USA 102(50):18129-18134

Wells JM, Rossi O, Meijerink M, van Baarlen P (2011) Epithelial crosstalk at the microbiota-mucosal interface. ProcNatlAcadSci USA 108(Suppl 1):4607-4614

Xiao L, Chen B, Feng D, Yang T, Li T, Chen J (2019) TLR4 may be involved in the regulation of colonic mucosal microbiota by vitamin a. Front Microbiol 10:268

Yan Z, Patricia AV, Dimitry MD et al (2008) Interleukin-22 mediates early host defense against attaching and effacing bacterial pathogens. Nat Med 14(3): 282-289

Zhang T, Li Q, Cheng L, Buch H, Zhang F (2019) Akkermansia muciniphila is a promising probiotics. Microb Biotechnol 12(6):1109-1125

Zhu H, Xu WY, Hu Z et al (2017) RNA virus receptor rig-I monitors gut microbiota and inhibits colitis-associated colorectal cancer. J Exp Clin Cancer Res 36(1):2

\section{Publisher's Note}

Springer Nature remains neutral with regard to jurisdictional claims in published maps and institutional affiliations. 